\title{
RANCANGAN PENGUKURAN KINERJA DENGAN BALANCE SCORECARD PADA SISTEM MANAJEMEN STRATEGI
}

\author{
Malikul Adil \\ Jurusan Teknik Industri \\ Universitas Muhammadiyah Gresik \\ Email : malikul_adil@hotmail.com
}

\begin{abstract}
$\mathrm{B}$ alance Scorecard represent a group of integrated performance measuring rod coming from company strategy from entire/all part of organization. Basically strategy represent a theory about how to reach the target of organization. In approach of Balance top management scorecard formulate its strategy into performance measuring rod, so that employees comprehend and can execute something to reach the strategy.

Balanced Scorecard represent a strategic management system or more precise named by: “ Based system accounting responsibility Strategic" what formulate strategy and mission an organization into target of performance measuring rod and operational to 4 different in perspective, that is is in perspective financial, in perspective customer, in perspective of internal business process and is in perspective of growth and learning.
\end{abstract}

Key words: performance measurement, balanced scorecard, perspective.

\section{PENDAHULUAN}

Balance scorecard merupakan sekelompok tolok ukur kinerja yang terintegrasi yang berasal dari strategi perusahaan dari seluruh bagian organisasi. Suatu strategi pada dasarnya merupakan suatu teori tentang bagaimana mencapai tujuan organisasi. Dalam pendekatan Balance scorecard manajemen puncak menjabarkan strateginya kedalam tolok ukur kinerja, sehingga karyawan memahaminya dan dapat melaksanakan sesuatu untuk mencapai strategi tersebut.

Balanced Scorecard merupakan suatu sistem manajemen strategik atau lebih tepat dinamakan suatu: "Strategic based responsibility accounting system" yang menjabarkan misi dan strategi suatu organisasi ke dalam tujuan operasional dan tolok ukur kinerja untuk 4 perspektif yang berbeda, yaitu perspektif keuangan (financial perspective), perspektif pelanggan (customer perspective), perspektif proses usaha internal (internal business process perspective) dan perspektif pembelajaran dan pertumbuhan (learning and growth perspective).

Balanced scorecard mempertahankan perspektif keuangan karena tolok ukur keuangan berguna dalam mengikhtisarkan konsekuensi tindakan ekonomi terukur yang telah diambil. Tolok ukur kinerja keuangan menunjukkan apakah strategi, implementasi, dan eksekusi perusahaan memberi kontribusi pada perbaikan laba. Tujuan finansial biasanya berkaitan dengan pengukuran kemampulabaan, seperti laba operasi, ROCE (Return-On-Capital Employed); EVA (Economic Value-Added) dan lain-lain. Tujuan keuangan alternatif dapat berupa pertumbuhan penjualan yang cepat atau perolehan arus kas. 
Perspektif keuangan menggambarkan konsekuensi tindakan ekonomi yang diambil dalam ketiga perspektif yang lain Perspektif pelanggan mendefinisikan pelanggan dan segmen pasar di mana unit usaha akan bersaing. Perspektif proses usaha internal melukiskan proses internal yang diperlukan untuk memberikan nilai untuk pelanggan dan pemilik.

Sebagai contoh, dalam perusahaan manufakturing, perakitan suatuproduk adalah proses usaha internal. Ide dasarnya adalah pembelajaran perlu untuk memperbaiki kepuasan pelanggan; dan memperbaiki kepuasan pelanggan perlu untuk memperbaiki hasil keuangan.

Akhirnya, perspektif pembelajaran dan pertumbuhan mendefinisikan kapabilitas yang diperlukan induk organisasi untuk menciptakan pertumbuhan jangka panjang dan perbaikan. dengan tiga "enabling factors" utama, yaitu:

1. Kapabilitas karyawan (employee capabilities);

2. Kapabilitas sistem informasi (information system capabilities); dan

3. Sikap karyawan (motivasi, pemberdayaan/ empowerment).

Dalam pendekatan Balanced scorecard, penekanan adalah pada perbaikan yang berkesinambungan (continuous improvement)bukan hanya mencapai tujuan khusus, seperti :laba dan sebagainya.

Apabila suatu organisasi tidak melakukan perbaikan yang berkesinambungan, organisasi tersebut mungkin akan kalah bersaing. Tolok ukur yang digunakan dalam Balanced Scorecard yang terdiri dari 4 kelompok di atas dapat digambarkan sebagai berikut:

Perspektif yang terakhir ini berhubungan

Translating Vision and Strategy : Four Perspectives

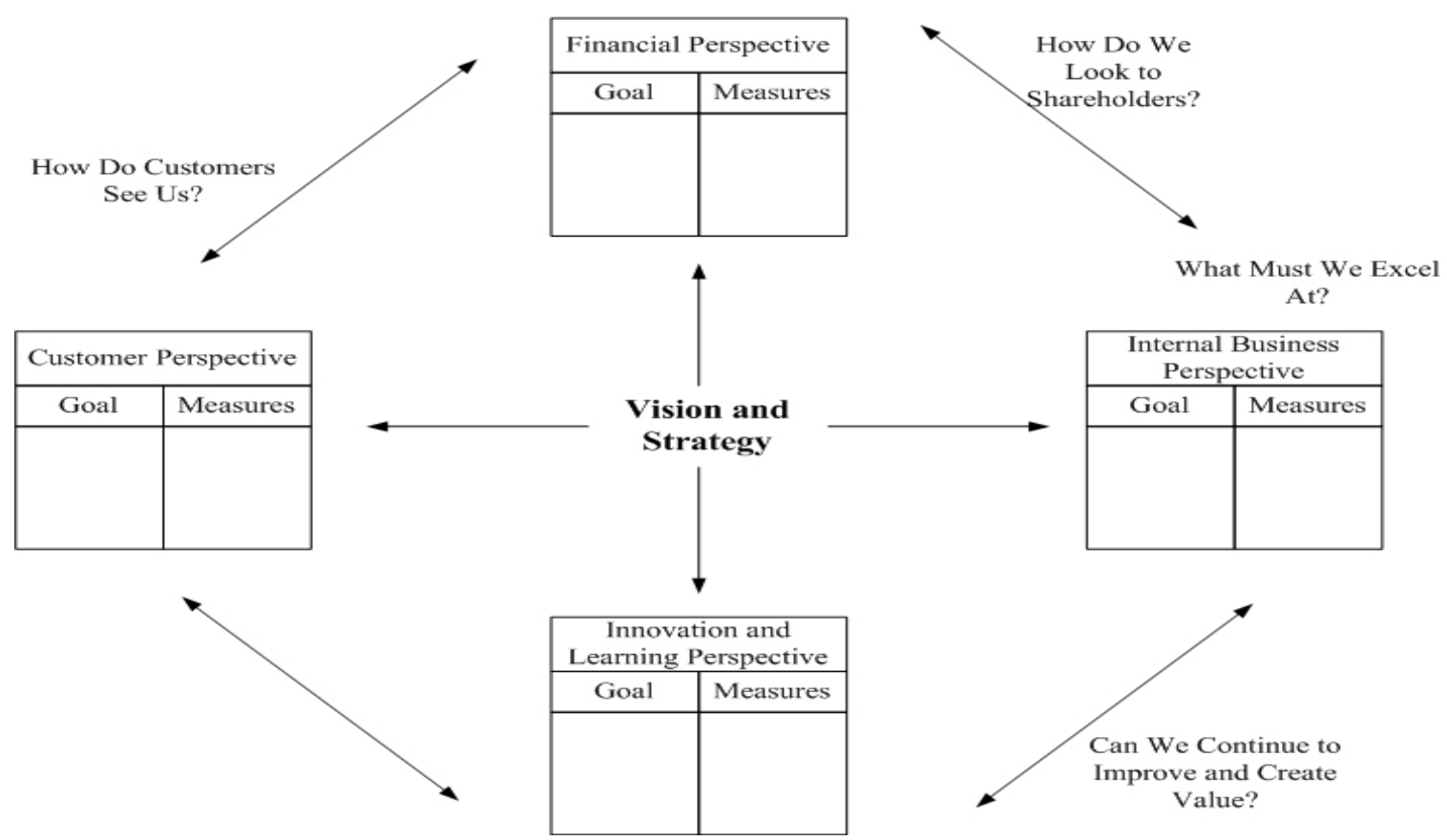

\section{METODE}

\section{Balanced Scorecard (BSC).}

Menurut Norton dan Kaplan(2000;7) merupakan sistem manajemen dalam bentuk kumpulan tujuan dan ukuran kinerja yang terintegrasi dan 124 diterjemahkan dari misi dan strategi perusahaan yang tersusun ke dalam empat perspektif : finansial, pelanggan, proses bisnis internal, serta pembelajaran dan pertumbuhan. BSC memberi kerangka kerja, bahasa, untuk mengkomunikasikan 
misi dan strategi. BSC menggunakan pengukuran untuk memberi informasi kepada para pekerja tentang faktor yang mendorong keberhasilan saat ini dan yang akan datang.

Tujuan dari pengukuran dari BSC berasal dari visi, misi dan strategi perusahaan yang dikelompokkan dalam empat perspektif yaitu finansial, pelanggan, proses bisnis internal dan pembelajaran dan pertumbuhan yang dibentuk dalam suatu kerangka (framework). Rerangka Balanced Scorecard dapat dilihat pada gambar dibawah ini.

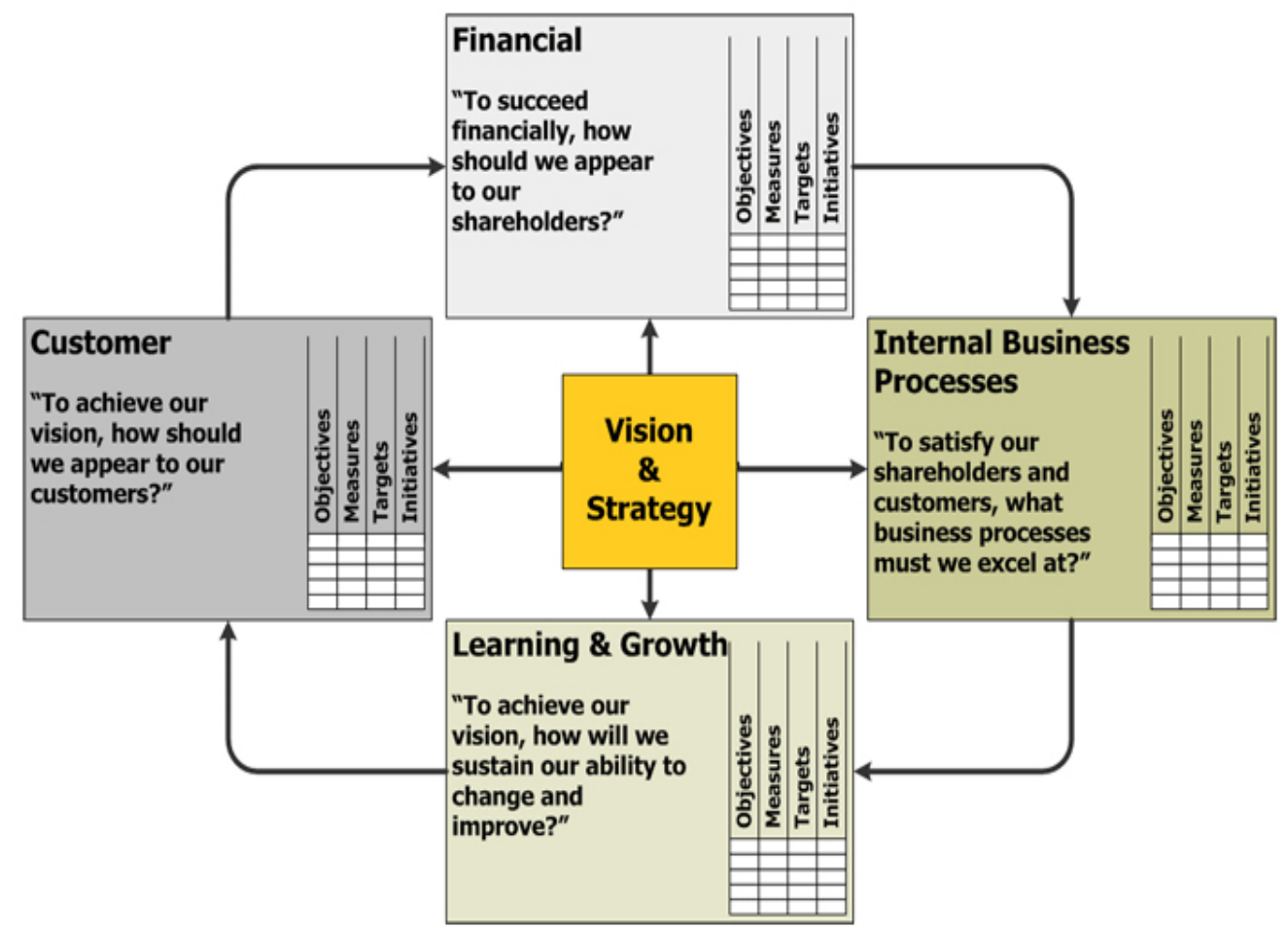

Gambar: Balanced Scorecard memberi Kerangka Kerja untuk Penerjemahan Strategi ke dalam Kerangka Operasional. Kaplan \& Norton $(2000 ; 8)$.

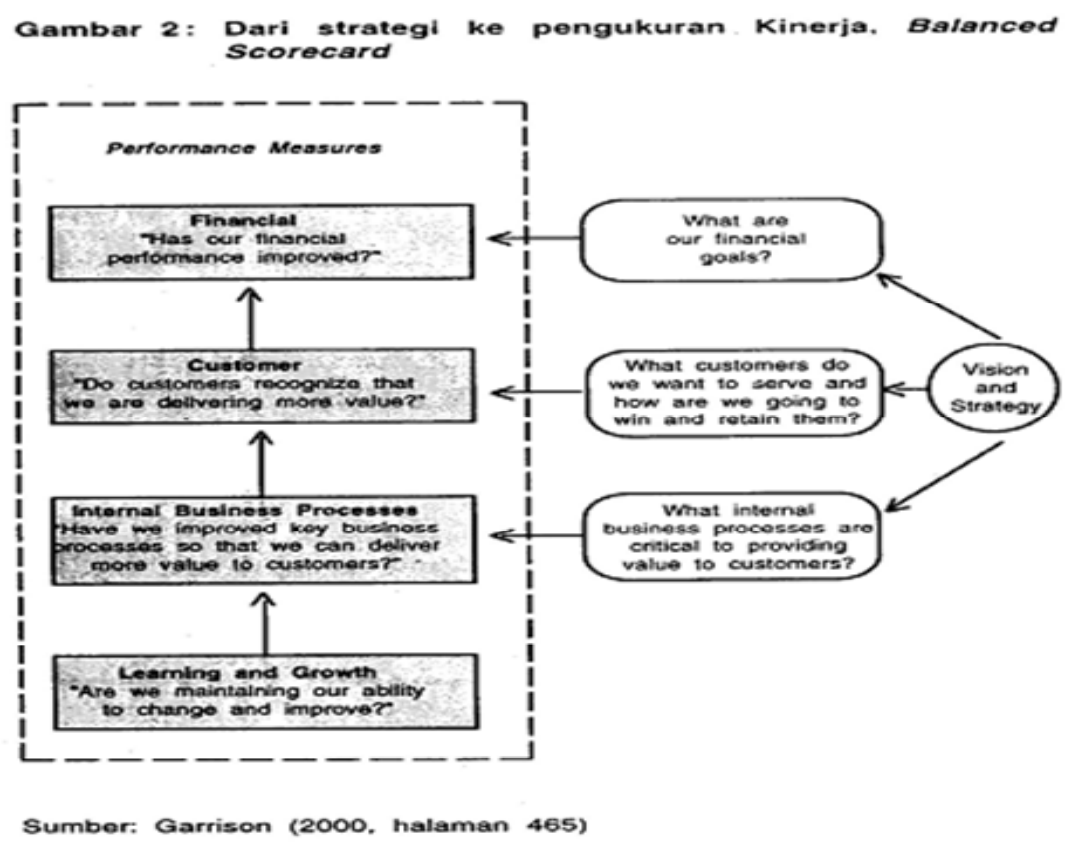


Tolok ukur keuangan tampak paling atas pada Gambar diatas. Pada akhirnya, eksistensi perusahaan untuk memberikan manfaat keuangan kepada pemilik. Organisasi yang tidak mencari keuntungan sekalipun harus menghasilkan sumber daya keuangan agar dapat bertahan dalam operasi. Biasanya, manajer puncak bertanggung jawab untuk tolok ukur kinerja keuangan bukan manajer tingkat lebih rendah. Gambar dibawah ini menyajikan contoh tolok ukur kinerja yang dapat ditemukan dalam Balanced Scorecard perusahaan. Gambar : Contoh tolok ukur kinerja dalam Balanced Scorecard

\begin{tabular}{|l|c|}
\hline Performance Measure & $\begin{array}{c}\text { Desired } \\
\text { Change }\end{array}$ \\
\hline $\begin{array}{l}\text { Customer satisfaction as measured } \\
\text { by survey results }\end{array}$ & + \\
\hline $\begin{array}{l}\text { Number of customer complaints } \\
\text { Market share }\end{array}$ & - \\
\hline $\begin{array}{l}\text { Product returns as a percentage of } \\
\text { sales }\end{array}$ & + \\
\hline $\begin{array}{l}\text { Percentage of customers } \\
\text { percentage from last period }\end{array}$ & + \\
\hline $\begin{array}{l}\text { Number of new customers } \\
\text { Performance Measure }\end{array}$ & $\begin{array}{c}\text { Desired } \\
\text { Change }\end{array}$ \\
\hline $\begin{array}{l}\text { Percentage of sales from new } \\
\text { products }\end{array}$ & + \\
\hline $\begin{array}{l}\text { Time to introduce new products to } \\
\text { market }\end{array}$ & - \\
\hline $\begin{array}{l}\text { Percentage of customer calls } \\
\text { answered within 20 seconds }\end{array}$ & + \\
\hline $\begin{array}{l}\text { On-time deliveries as a percentage } \\
\text { of all deliveries }\end{array}$ & + \\
\hline $\begin{array}{l}\text { Work in process inventory as a } \\
\text { percentage of sales }\end{array}$ & - \\
\hline $\begin{array}{l}\text { Unfavorable standard cost } \\
\text { variances }\end{array}$ & - \\
\hline $\begin{array}{l}\text { Defect-free units as a percentage } \\
\text { of completed units } \\
\text { Delivery cycle time }\end{array}$ & - \\
\hline Throughput time & - \\
\hline \begin{tabular}{l} 
Manufacturing cycle efficiency \\
\hline Quality costs
\end{tabular} & - \\
\hline $\begin{array}{l}\text { Setup time } \\
\text { Time from call by customer to } \\
\text { epair of product }\end{array}$ & - \\
\hline $\begin{array}{l}\text { Percent of customer complaints } \\
\text { settled on first contact }\end{array}$ & - \\
\hline Time to settle a customer claim & - \\
\hline
\end{tabular}

\begin{tabular}{|l|c|}
\hline $\begin{array}{l}\text { Learning and Growth } \\
\text { Perspective } \\
\text { Performance Measure }\end{array}$ & $\begin{array}{c}\text { Desired } \\
\text { Change }\end{array}$ \\
\hline Suggestions per employee & + \\
\hline Value-added employee & + \\
\hline $\begin{array}{l}\text { Employee turnover } \\
\text { Hours of in-house training per } \\
\text { employee }\end{array}$ & - \\
\hline
\end{tabular}

Sumber: Garrison, (2000, hal. 466)

Nils-Goran Olve, dan kawan-kawan dalam buku A practical Guide to Using Balanced Scorecard: Performance Drivers (1999, hal 327 sampai dengan 332) memberikan contoh tolok ukur dalam perspektif yang berbeda sebagai berikut:

\section{FINANCIAL PERSPECTIVE}

1. Total assets (\$)

2. Total assets/employee (\$)

3. Revenues/total assets (\%)

4. Revenues from new products or business operations (\$)

5. Revenues/employee (\$)

6. Profit/total assets (\%)

7. Profits from new products or business operations (\$)

8. Profits/employee (\$)

9. Market value (\$)

10. Return on net assets (\%)

11. Value added/employee (\$)

12. Return on total assets (\%)

13. Return on capital employed (\%)

14. Profit margin (\%)

15. Contribution/revenue, or contribution margin (\%)

16. Contribution/employee (\$)

17. Cash flow (\$)

18. Shareholder equity/total assets, or solvency (\%)

19. Return on investment (\%)

20. Total costs (\$) 


\section{CUSTOMER PERSPECTIVE}

1. Number of customers (No.)

2. Market share (\%)

3. Annual sales/customer (\$)

4. Customers lost (No. or \%)

5. Average time spent on customer relations (No.)

6. Customers/employee (No. or \%)

7. Sales closed/sales contacts (\%)

8. Satisfied-customer index (\%)

9. Customer-loyalty index (\%)

10. Cost/customer (\$)

1. Number of visits to customers (No.)

2. Number of complaints (No.)

3. Marketing expenses (\$)

14. Brand-image index (\%)

15. Average duration of customer relationship (No.)

14. Average customer size (\$)

16. Customer rating (\%)

17. Customer visits to the company (No.)

15. Average time from customer contact to sales response (No.)

16. Service expense/customerlyear (\$)

\section{PROCESS PERSPECTIVE}

1. Administrative expense/total revenues (\%)

2. Processing time, outpayments (No.)

3. On-time delivery (\%)

4. Average lead time (No.)

5. Lead time, product development (No.)

6. Lead time, from order to delivery (No.)

7. Lead time, suppliers (No.)

8. Lead time, production (No.)

9. Average time for decision-making (No.)

10. Inventory turnover (No.)

11. Improvement in productivity (\%)

12. IT capacity [CPU and DASD] (No.)

13. IT capacity/employee (No.)

14. Change in IT inventory (\$ or \%)
15. IT expense/administrative expense (\%)

16. Emissions from production into the environment (No.)

17. Environmental impact of product use (No.)

18. Cost of administrative error/management revenues (\%)

19. Contracts filed without error (No.)

20. Administrative expenselemployee (\$)

RENEWAL AND DEVELOPMENT

PERSPECTIVE

1. $R \& D$ expense (\$)

2. $R \& D$ expense/total expenses (\%)

3. IT development expense/IT expense (\%)

4. Hours, $R \& D(\%)$

5. $R \& D$ resources/total resources $(\%)$

6. Investment in training/customers (No.)

7. Investment in research (\$)

8. Investment in new product support and training (\$)

9. Investment in development of new markets (\$)

10. Direct communications to customers/year (No.)

11. Patents pending (No.)

12. Average age of company patents (No.)

13. Suggested improvements/employee (No.)

14. Competence developments/employee (No.)

15. Satisfied-employee index (No.)

16. Marketing expense/customer (\$)

17. Employee's view (empowerment index) (No.)

18. Share of employee below age X (\%)

19. Non-product/related expense/customer/year (\$)

20. Ratio of new products (less than $X$ years old) to full company catalogue (\%)

\section{Analytic Hierarchy Process.}

Suatu hirarki fungsional dengan input utama persepsi manusia. Dengan hirarki, masalah komplek dan tidak terstruktur dapat dipecah ke dalam masing-masing kelompoknya. Kelompok tersebut kemudian diatur menjadi suatu bentuk hirarki. 
Langkah-langkah dalam menggunakan metode AHP :

1. Definisikan masalah dan tentukan penyelesaian yang diinginkan.

2. Menyusun struktur hirarki dimulai dengan tujuan umum dan diteruskan dengan sub-tujuan dan alternatif pada tingkat kriteria yang paling rendah.

3. Membuat matrix perbandingan yang menunjukkan kontribusi pengaruh setiap elemen terhadap masing-masing tujuan yang berada setingkat diatasnya. Nilai perbandingan secara berpasangan antara $\left(\mathrm{x}_{\mathrm{i}}, \mathrm{x}_{\mathrm{j}}\right)$ dapat dipresentasikan seperti matrix perbandingan berpasangan, yaitu :

$\mathrm{x}_{\mathrm{i}} / \mathrm{x}_{\mathrm{j}=\mathrm{a}} \mathrm{a}(\mathrm{i}, \mathrm{j})$, dimana $\mathrm{i}, \mathrm{j}=1,2,3$ .,n.

Setiap elemen mempunyai sifat timbal balik, yaitu $\mathrm{a}_{\mathrm{ij}}=1 / \mathrm{a}_{\mathrm{ji}}$.

Bila vektor pembobotan elemen operasi A1, A2,..... An dinyatakan sebagai vektor W, maka matrix pada gambar 4. dapat berubah menjadi matrix perbandingan preferensi seperti gambar 5 .

4. Melakukanperbandingan berpasangansehingga diperoleh pertimbangan secara keseluruhan sebanyak $\mathrm{n} \times\{(\mathrm{n}-1) / 2\}$ buah dengan $\mathrm{n}$ adalah jumlah elemen yang dibandingkan.

\begin{tabular}{|l|l|l|l|}
\hline & A1 & $\ldots$ & An \\
\hline A1 & a11 & $\ldots$. & a1n \\
\hline$\ldots$. & $\ldots$. & $\ldots$. & $\ldots$. \\
\hline An & an1 & $\ldots$. & ann \\
\hline
\end{tabular}

Gambar 4. Matrix Perbandingan Berpasangan

\begin{tabular}{|l|l|l|l|}
\hline & A1 & $\ldots$. & An \\
\hline A1 & w1/w1 & $\ldots$. & w1/wn \\
\hline$\ldots$. & $\ldots$. & $\ldots$. & $\ldots$. \\
\hline An & wn $/$ w1 & $\ldots$. & wn $/$ wn \\
\hline
\end{tabular}

Gambar 5. Matrix Perbandingan Preferensi

5. Menghitung eigen vector dan menguji konsistensinya, jika tidak konsisten pengambilan data diulang.

6. Mengulang langkah 3, 4 dan 5 untuk seluruh tingkat hirarki.

7. Menghitung eigen vektor dari setiap matrix perbandingan berpasangan.

8. Memeriksa konsistensi hirarki, bila nilainya lebih besar dari 100\%, penilaian data pertimbangan harus direvisi.

\section{Uji Konsistensi.}

AHP mengukur konsistensi secara menyeluruh dari berbagai pertimbangan melalui rasio konsistensi. Nilai rasio konsistensi harus lebih kecil atau sama dengan $10 \%$, apabila rasio lebih besar dari $10 \%$ perlu direvisi.

Pengukuran konsistensi dari suatu matrix didasarkan pada suatu eigen vector maksimum, rumus dari Indeks Konsistensi (IK) :

$$
\begin{aligned}
\mathrm{IK}=\left(\lambda_{\text {maks }}-\mathrm{n}\right) /(\mathrm{n} & -1) \\
\operatorname{Dimana}: \lambda & =\text { eigen vector } \\
\mathrm{n} & =\text { ukuran matrix } \\
\mathrm{IK} & =\text { Indeks Konsistensi }
\end{aligned}
$$

Eigen vector maksimum suatu matrix tidak akan lebih kecil dari n, sehingga tidak ada nilai IK yang negatif. Semakin dekat eigen vector dengan besarnya matrix, semakin konsisten matrix tersebut. Adapun rumus rasio konsistensi adalah :

$$
\begin{aligned}
& \mathrm{RK}=\mathrm{IK} / \mathrm{IR} \\
& \text { Dimana : RK = Rasio Konsistensi } \\
& \text { IK }=\text { Indeks Konsistensi } \\
& \text { IR = Indeks Random }
\end{aligned}
$$

\section{Indeks Random :}

Menyatakan rata-rata konsistensi dari matrix perbandingan berukuran 1 sampai dengan 10 yang didapatkan dari Oak Ridge National Laboratory dan kemudian dikembangkan oleh Wharton School.

\section{Scoring}

Didalam melakukan pengukuran kinerja untuk masing-masing sasaran strategik/KPI perlu dilakukan scoring, dimana scoring tersebut 
digunakan untuk : menyatukan dimensi dari masing-masing satuan sasaran strategik sehingga diperoleh ukuran kinerja tunggal dan membuat standar penilaian masing- masing sasaran strategik berdasarkan target dan pencapaian serta pembatasannya dengan metode Objective Matrix (OMAX), Riggs (1980), Parsons (2000), yaitu diukur berdasarkan tingkat produktivitas awal diberi nilai 3 sedang tingkat produktivitas yang diinginkan diberi nilai 10 .

\section{Perspektif (Perspectives)—empat:}

Pengendalianorganisasi.Perspektifmemberikan suatu kerangka kerja untuk pengukuran. Empat perspektif dalam Balanced Scorecard adalah: (1) Finansial (final outcomes), (2) Pelanggan, (3)
Pertumbuhan.

\section{Hubungan Sebab-Akibat (Cause-Effect Relationship)_aliran :}

Kinerja bisnis dari tingkat lebih rendah (lower level) ke tingkat lebih tinggi (upper lever) di dalam atau di antara perspektif. Misalnya, pelatihan karyawan tentang pelayanan pelanggan akan mengakibatkan pelayanan pelanggan menjadi lebih baik, sehingga memimpin ke arah peningkatan hasil-hasil finansial. Hubungan sebab-akibat menunjukkan sebagai pemimpin atau pengendali pada satu sisi, menghasilkan suatu hasil akhir atau akibat pada sisi yang lain. Contoh hubungan sebabakibat dalam empat perspektif Balanced Scorecard ditunjukkan dalam Bagan sebagai berikut :

Proses Bisnis Internal, dan (4) Pembelajaran \&

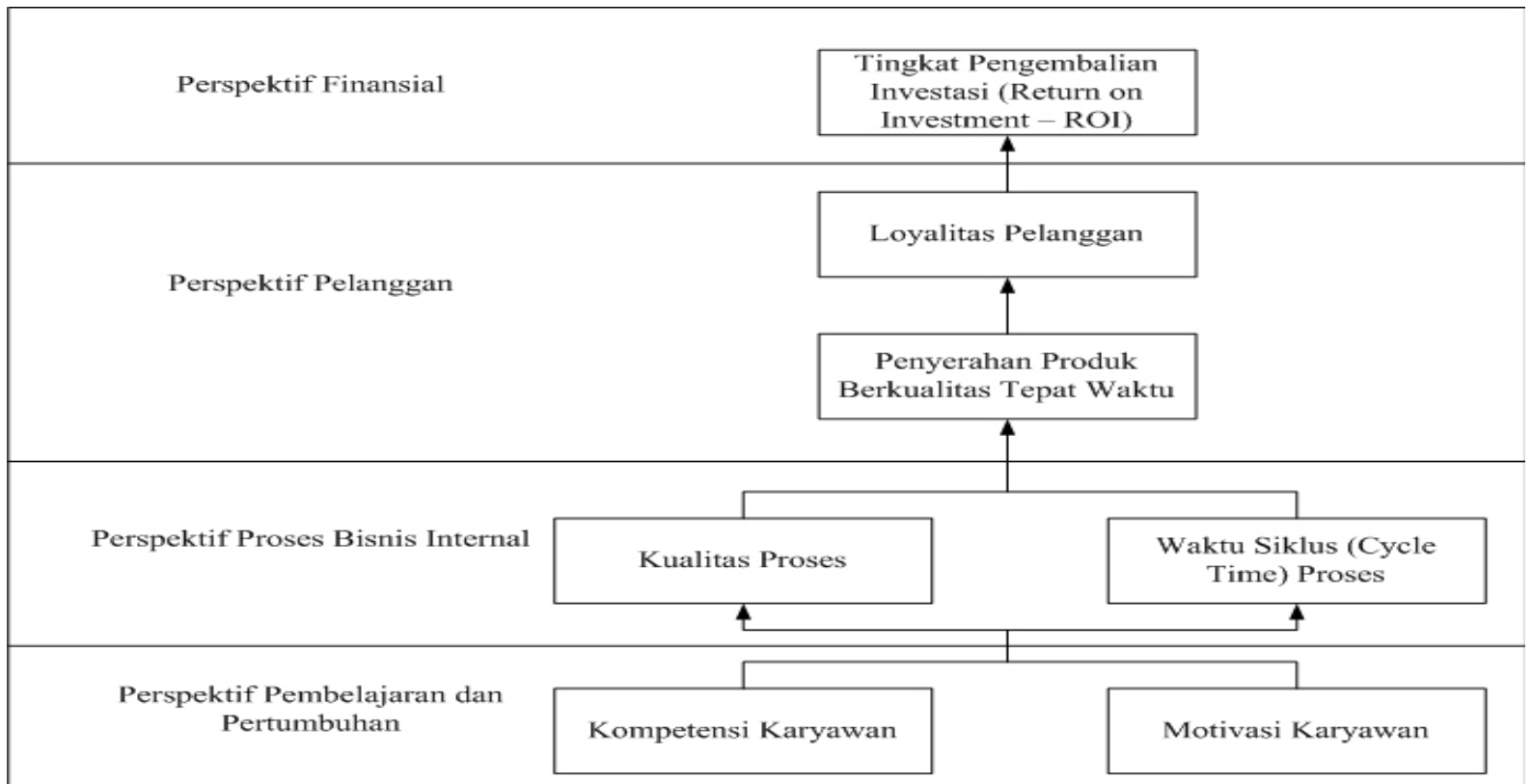

\section{Pengukuran (Measurement):}

Suatu cara memantau dan menelusuri kemajuan tujuan-tujuan strategis. Pengukuran dapat berupa indikator yang memimpin kinerja -memimpin menuju hasil akhir (leading/lead indicators) atau hasil akhir (lagging/ lag indicators). Misalnya, perspektif pelanggan yang bertujuan meningkatkan tingkatkepuasan pelanggan $100 \%$ pada akhir tahun 2002 (tujuan strategis) dapat diukur menggunakan indikator keakuratan dalam pelayanan, tanggap dalam pelayanan, harga dan kualitas produk dibandingkan pesaing-pesaing (lead indicators), rating kepuasan pelanggan, dan indikator banyaknya pelanggan yang merasa puas (lag indicators). Lag indicators sering disebut sebagai ukuran-ukuran outcome (outcome measures), sedangkan lead indicators disebut sebagai ukuran-ukuran pengendali kinerja (performance driver measures). Lag indicators dan lead indicators merupakan indikator kinerja kunci (key performance 
indicators) bagi suatu organisasi.

\section{Target (Targets):}

Suatu tingkat kinerja yang diharapkan atau peningkatan yang diperlukan di masa mendatang. Misalnya, perspektif finansial memiliki target kinerja tingkat pengembalian investasi (ROI) minimum $35 \%$ per tahun, perspektif pelanggan memiliki target kinerja kepuasan pelanggan $100 \%$, perspektif proses bisnis internal memiliki target kinerja tingkat kegagalan produk maksimum 100 DPMO (defects per million opportunities), dan perspektif pembelajaran dan pertumbuhan memiliki target kinerja pelatihan karyawan minimum 45 jam per karyawan per tahun.

\section{Program (Programs):}

Inisiatif-inisiatif atau proyek-proyek utama yang harus dilaksanakan agar memenuhi satu atau lebih tujuan-tujuan strategis. Misalnya, program peningkatan efisiensi, program peningkatan kualitas, program peningkatan kepuasan pelanggan, dan program peningkatan produktivitas merupakan program-program yang sering dilaksanakan dalam organisasi bisnis.

\section{Pemikiran Strategis (Strategic Thinking) :}

Suatu proses intuitif dan alamiah dalam berpikir yang melihat sesuatu melalui kompetisi, mengantisipasi kecenderungan masa depan, dan secara komprehensif memikirkan perubahanperubahan yang dibutuhkan untuk menghadapi tantangan di masa depan. Pemikiran strategis dapat diterapkan pada individu maupun organisasi.

\section{Perencanaan Strategis (Strategic Planning) :}

Suatu proses formal yang terstruktur dalam pencarian kembali dan analisis tentang kompetisi sebagai suatu usaha untuk mengidentifikasi kekuatan-kekuatan, kelemahan-kelemahan, kesempatankesempatan, dan tantangan-tantangan atau ancaman-ancaman (SWOT analysis).

\section{Kisi Strategis (Strategic Grid) :}

suatu kerangka kerja logis untuk mengorganisasikan sekumpulan tujuan strategis ke dalam empat perspektif dalam Balanced Scorecard. Segala sesuatu dikaitkan untuk membangun hubungan sebab-akibat. Kisi strategis merupakan landasan untuk membangun Balanced Scorecard, misalnya kisi strategis yang mengorganisasikan tujuan-tujuan strategis dalam perspektif finansial dari Balanced Scorecard seperti ditunjukkan dalam Bagan sebagai berikut :

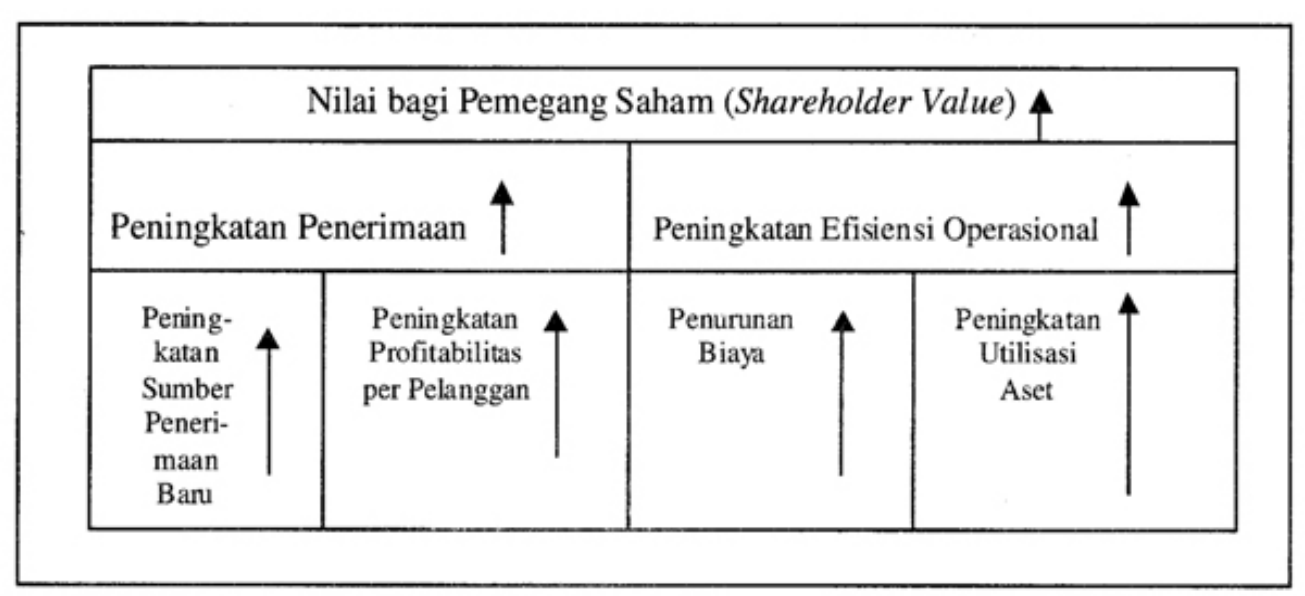

Bagan I.3 Contoh Kisi Strategis untuk Perspektif Finansial dalam Balanced Scorecard 


\section{Area Strategis (Strategic Area) :}

Tujuan strategis utama untuk organisasi, misalnya memaksimumkan nilai pemegang saham atau meningkatkan efisiensi operasional. Area strategis mendefinisikan ruang lingkup untuk pembangunan sistem balanced scorecard.

\section{Model Strategis (Strategic Model) :}

Kombinasi dari semua tujuan strategis pada suatu kisi strategis (strategic grid), dikaitkan secara baik dan lengkap, memberikan satu model tunggal atau struktur untuk mengelola area strategis.

\section{Strategi :}

Suatu pernyataan tentang apa yang harus dilakukan oleh organisasi untuk bertindak dari satu titik referensi ke titik referensi yang lain. Strategi merupakan sekumpulan .tindakan terintegrasi yang konsisten dengan visi jangka panjang organisasi yang memberikan nilai kepada pelanggan dengan suatu struktur biaya yang memungkinkan pencapaian keunggulan hasil yang berkelanjutan. Dalam konteks definisi ini, setiap organisasi yang berorientasi pada keuntungan atau yang nirlaba (not for profit) merupakan suatu sistem penyerahan nilai (value delivery system). Strategi biasanya dikembangkan pada tingkat atas organisasi, tetapi dilaksanakan oleh tingkat bawah organisasi.

\section{Templates :}

Alat-alat visual untuk membantu dalam pembangunan balanced scorecard, secara tipikal digunakan untuk memperoleh dan membandingkan data dalam empat komponen balanced scorecard, yaitu: (1) kisi strategis, (2) pengukuran, (3) target, dan (4) program (inisiatif).

\section{Transformasi Strategi Menjadi Tindakan \\ Melalui Balanced Scorecard}

Balanced Scorecard merupakan suatu konsep manajemen yang membantu menerjemahkan strategi ke dalam tindakan. Balanced Scorecard adalah lebih dari sekadar suatu sistem pengukuran operasional atau taktis. Perusahaan-perusahaan yang inovatif menggunakannya sebagai suatu sistem manajemen strategis yang mengelola strategi perusahaan sepanjang waktu. Perusahaan-perusahaan inovatif itu menggunakan fokus pengukuran balanced scorecard untuk melaksanakan proses-proses manajemen kritis, sebagai berikut:

1. Mengklarifikasi dan menerjemahkan visi dan strategi perusahaan.

2. Mengkomunikasikan dan mengaitkan tujuantujuan strategis dengan ukuran-ukuran kinerja.

3. Merencanakan, menetapkan target, dan menyelaraskan inisiatif-inisiatif (programprogram) strategis.

4. Mengembangkan umpan-balik dan pembelajaran strategis untuk peningkatan terusmenerus di masa yang akan datang.

Dari uraian singkat di atas tampak bahwa balanced scorecard dimulai dari visi dan strategi perusahaan, di mana dari sini berbagai faktor kesuksesan yang penting didefinisikan. Ukuranukuran kinerja dibangun sebagai alat bantu untuk menetapkan target dan mengukur kinerja dalam area kritis tujuan-tujuan strategis. Dengan demikian balanced scorecard merupakan suatu sistem pengukuran kinerja manajemen atau sistem manajemen strategis, yang diturunkan dari visi dan strategi dan merefleksikan aspek-aspek terpenting dalam suatu bisnis.

Pada umumnya, sistem manajemen tradisional berfokus pada anggaran (budgets), sehingga pelaksanaan strategi perusahaan sangat tergantung pada anggaran yang tersedia, seperti ditunjukkan dalam Bagan dibawah ini . Hal ini berbeda dari sistem manajemen strategis balanced scorecard yang berfokus pada proses-proses manajemen strategis, sehingga strategi perusahaan melalui balanced scorecard diterjemahkan menjadi tindakantindakan yang terarah seperti ditunjukkan dalam Bagan 1.5. 


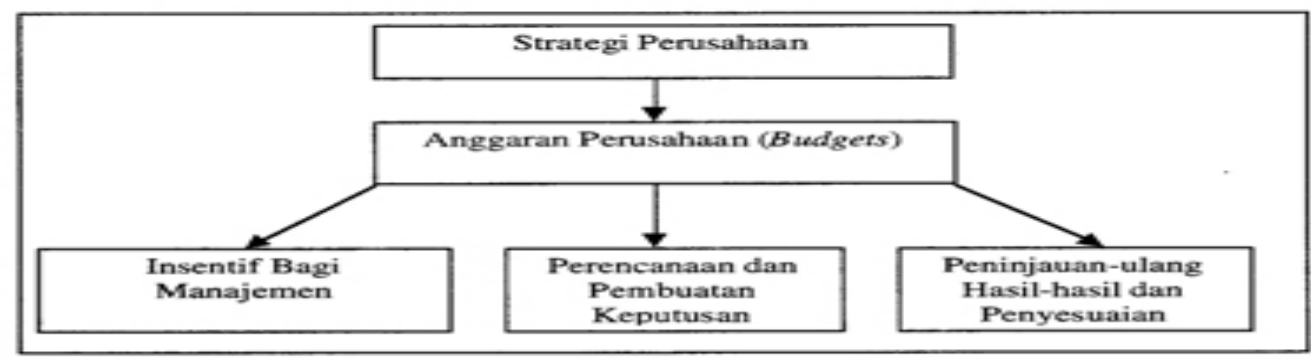

Bagan I.4 Sistem Manajemen Tradisional

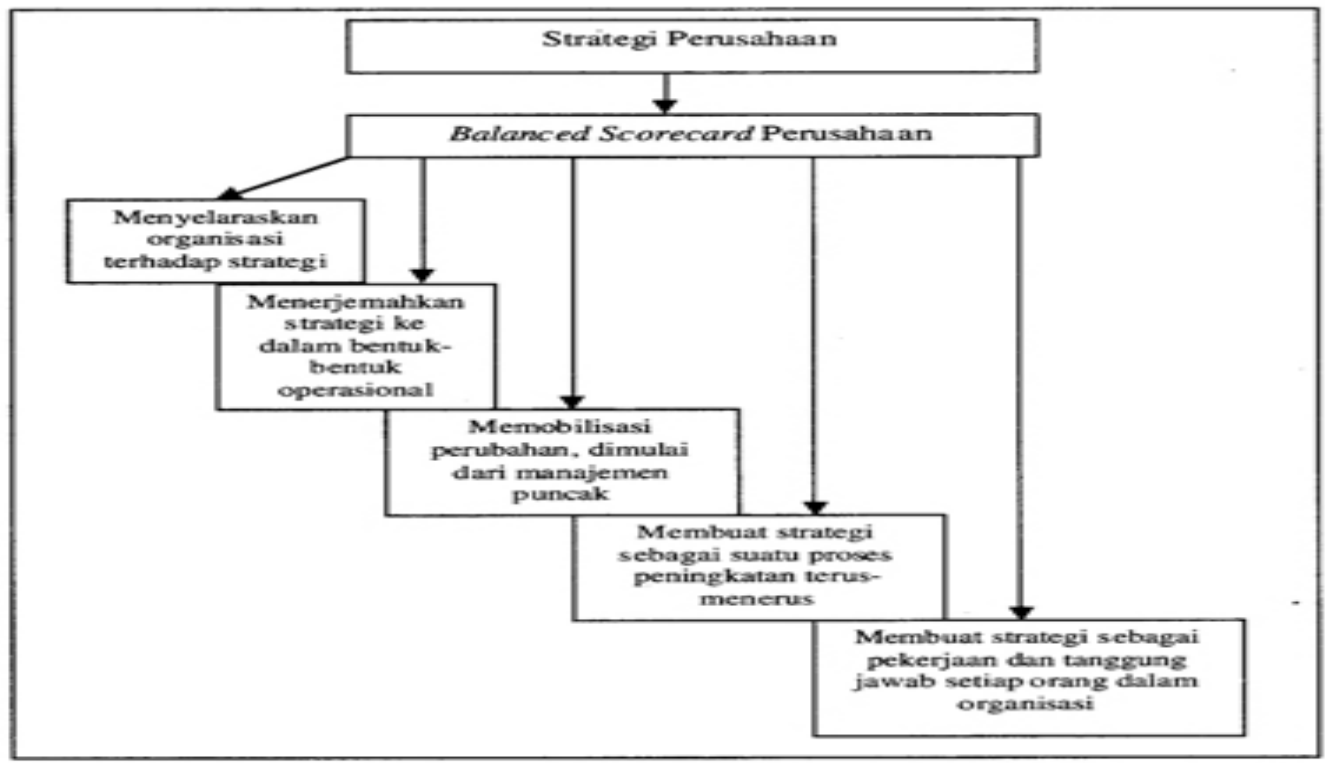

Bagan I.5 Sistem Manajemen Strategis Balanced Scorecard

Sebagai konsekuensi dari perbedaan praktek sistem manajemen tradisional dan sistem manajemen strategis balanced scorecard, pelaporan pada sistem manajemen tradisional semata-mata digunakan sebagai alat pengendalian (control reporting), sedangkan pelaporan pada sistem manajemen strategis balanced scorecard digunakan sebagai alat strategis (strategic reporting). Perbedaan kedua bentuk pelaporan ini ditunjukkan dalam Tabel sebagai berikut : Perbedaan antara Pelaporan Pengendalian dan Pelaporan Strategis

\begin{tabular}{|c|c|}
\hline $\begin{array}{l}\text { Pelaporan Pengendalian } \\
\text { (Manajemen Tradisional) }\end{array}$ & $\begin{array}{c}\text { Pelaporan Strategis } \\
\text { (Manajemen Balanced Scorecard) }\end{array}$ \\
\hline $\begin{array}{l}\text { Pengendalian melalui anggaran } \\
\text { Berfokus pada fungsi-fungsi dalam } \\
\text { organisasi } \\
\text { Mengabaikan pengukuran kinerja atau } \\
\text { pengukuran kinerja dilakukan secara } \\
\text { terpisah } \\
\text { Informasi fungsional tunggal (hanya untuk } \\
\text { keperluan satu fungsi dalam organisasi) }\end{array}$ & $\begin{array}{l}\text { Umpan-balik dan pembelajaran } \\
\text { Berfokus pada tim fungsional silang } \\
\text { (cross-functional teams) } \\
\text { Pengukuran kinerja terintegrasi yang } \\
\text { dilakukan berdasarkan hubungan sebab- } \\
\text { akibat } \\
\text { Informasi fungsional silang dan disebar- } \\
\text { luaskan ke seluruh fungsi dalam organisasi }\end{array}$ \\
\hline
\end{tabular}




\section{KESIMPULAN}

Dari kesimpulan yang telah disampaikan diatas, disarankan hal-hal sebagai berikut :

1. Penilaian kinerja dengan menggunakan metode Balanced Scorecard akan membantu memudahkan manajemen dalam melakukan evaluasi kinerja dan mengendalikan perusahaan, oleh karena dengan metode ini perusahaan dapat mengetahui hal-hal sebagai berikut :

a. Tujuan utama penurunan biaya operasional.

b. Keinginan dan kebutuhan pelanggan/ user.

c. Kualitas pelayanan, produk dan jasa.

d. Efektifitas dan efisiensi operasi internal.

e. Motivasi dan pemahaman karyawan dalam memajukan perusahaan.

2. Bila memungkinkan, hasil rancangan sistim pengukuran kinerja menggunakan metode Balanced Scorecard ini digunakan sebagai pemicu pencapaian target berdasarkan anggaran yang ditetapkan.

3. Dalam mengaplikasikan sistim pengukuran kinerja ini memerlukan komitmen dari pihak manajemen dan seluruh karyawan serta kesiapan sumber daya perusahaan.

\section{DAFTAR PUSTAKA}

Gasperz, Vincent, 2003, Sistem Manajemen Kinerja Terintegrasi Balanced Scorecard Dengan Six Sigma Untuk Organisasi Bisnis dan Pemerintah, Gramedia Pustaka Utama, Jakarta.

Kaplan, R.S. dan Norton, D.P, 1996. Balanced Scorecard Translating Strategy Into Action, Harvard Business School Press, AS, alih bahasa Yosi Pasla, Peter R, (2000) Erlangga, Jakarta.

Lee, Dean R., The Objective Matrix A Measurement/Management Tool for Process/ Product Improvement, Bloodworth Integrated Technology.
Mulyadi, 2001.AlatManajemen Kontemporeruntuk Pelipatganda Kinerja Keuangan Perusahaan : Balanced Scorecard, Salemba Empat, Jakarta.

Mulyadi, 2005, Sistem Manajemen Strategik Berbasis Balanced Scorecard, UPP AMPYKPN, Yogyakarta.

Parsons, John., 2000. Data to Information, Information to Knowledge and Knowledge to Decision \& Action, Report on the APO Symposium on Productivity Measurement in the Service Sector, Asian Productivity Organization, Tokyo, Japan.

Saaty, Thomas L and Kearns, Kevin P., 1985. Analytical Planning : The Organization of System, Pergamon Press.

Saaty, Thomas L. (1998) Descision Making For Leaders : The Analytical Hierarchy Process For $Z$ decision in a Complex World, University of Pittsburgh.

Sony Yuwono, Edy Sukarno, Muhammad Ichsan (2003) Petunjuk Praktis Penyusunan Balanced Scorecard Menuju Organisasi yang Berfokus pada Strategy, Gramedia Pustaka Utama Jakarta

Wahyudi, A.S. (1996) Manajemen Strategik: Pengantar Proses Berpikir Strategik, Binarupa Aksara, Jakarta.

Widjaja Tunggal, Amin (2000) Pengukuran Kinerja dengan Balance Scorecard, Harvarindo, Jakarta. 